Volume 1 No (2) 2018

\title{
EKSEPSI TERHADAP KEWENANGAN PENGADILAN NEGERI PADANGSIDIMPUAN DALAM MENGADILI PEMBAGIAN HARTA WARISAN
}

\author{
Syamsir Alam Nasution ${ }^{1}$ \\ ${ }^{1}$ Fakultas Hukum Universitas Muhammadiyah Tapanuli Selatan, Sumatera Utara
}

\begin{abstract}
ABSTRAK
Berdasarkan materi yang diambil dalam penelitian ini sebagaimana tersebut di atas dimana kita ketahui bahwa dalam perkara perdata tentang masalah harta warisan masih banyak lagi masyarakat yang belum mengetahui bahwa peradilan manakah yang berhak untuk memeriksa pembagian harta warisan, dan sejauh manakah kewenangan peradilan umum dalam eksepsinya terhadap maslah harta warisan tersebut. Tujuan dilakukannya penelitian ini adalah untuk mengetahui kewenangan Hakim Pengadilan Negeri dalam mengadili perkara pembagian harta warisan sudah berkekuatan hokum dan untuk mengetahui bagaimana kekuatan hukumnya pembagian harta warisan yang disidangkan di Pengadilan Negeri Padangsidimpuan Selanjutnya metode penelitian yang penulis gunakan dalam penulisan penelitian ini adalah penelitian kualitatif yang maksudnya adalah penelitian yang dilakukan dengan hasil wawancara penulis dengan responden dan juga melakukan penelitian terhadap data-data dan Putusan Pengadilan Negeri Padangsidimpuan yang berkaitan dengan penelitian ini dan juga dengan cara melakukan Penelitian Lapangan (Library Research) dan Penelitian Kepustakaan (Field Research), Sedangkan teknik atau alat yang penulis gunakan dalam mengumpulkan data baik dilapangan maupun dalam melakukan wawancara dengan responden yang ditemui penulis serta data yang diambil dari dokumen yang berkaitan dengan permasalahan yang dirumuskan dalam penelitian ini yaitu Interview (Wawancara) dan Studi Dokumentasi yaitu dengan mempelajari berkas-berkas yang telah diarsipkan di Pengadilan Negeri Padangsidimpuan yang selanjutnya akan dianalisan dengan cara Induksi dan Deduksi. Sebagai kesimpulannya bahwa kewenangan Hakim Pengadilan Negeri dalam mengadili perkara pembagian harta warisan sudah berkekuatan hukum sekalipun sudah terbentuknya Undang-undang Nomor 50 tahun 2009 perubahan atas Undang-undang Nomor 3 Tahun 2006 dan juga perubahan Undang-undang Nomor 7 Tahun 1989 yang mengatur tentang kewenangan Pengadilan Agama karena tidak terlepas dari Undang-undang Nomor 48 Tahun 2009 tentang Pokok Kekuasaan Kehakiman yang menyatakan Pengadilan Negeri berhak mengadili dan memeriksa perkara harta warisan akan tetapi kita tidak boleh terlepas dengan adanya Undang-undang yang berhak mengadili dan memeriksa serta memutus perkara harta warisan yaitu Pengadilan Agama dan bahwa kekuatan kewenangan Pengadilan Negeri untuk menyidangkan sengketa warisan Islam khususnya tentang masalah yang berkaitan dengan sengketa kepemilikan harta warisan adalah bersifat mutlak akan tetapi pelaksanaan putusan yang dikeluarkan berdasarkan kewenangan Hakim Pengadilan Negeri yang sesuai dengan apa yang terdapat di dalam Undang-undang Nomor 48 Tahun 2009.
\end{abstract}

Kata Kunci : Pembagian Harta Warisan, Kewenangan Pengadilan

\section{PENDAHULUAN}


Sebagaimana di dalam sejarah kehidupan manusia mengalami 3 (tiga) peristiwa yang penting yaitu: kelahiran, perkawinan dan kematian. Dengan lahirnya seorang anak, akan timbul suatu hak dan kewajiban baru antara orang tua dan anak yang dilahirkan tersebut. Hak dan kewajiban tersebut melekat hingga anak tersebut dewasa, sehingga pada waktu phase berikutnya yaitu perkawinan. Perkawinan merupakan basis masyarakat yang baik dan teratur yang tidak hanya diikat oleh ikatan lahir tetapi juga diikat oleh ikatan batin dan jiwa. Salah satu tujuan dari perkawian adalah memperoleh keturunan yang sah, dan pula sebagaimana kondisi manusia yang normal, perkawinan tersebut akan menghasilkan anak, anak inilah yang kelak dikemudian hari akan melanjutkan sejarah dan nama keluarga, maka si anak inilah yang dinamakan sebagai ahli waris dan ia berhak atas segala hal yang ditinggalkan orang tuanya, jika kelak orang tua mereka meninggal dunia

Setelah si anak ditinggal mati orang tuanya, akan mengakibatkan timbulnya suatu goncangan atau suatu gangguan keseimbangan kehidupan, baik di dalam kehidupan masyarakat, lingkungan maupun diantara keluarga sendiri. gangguan itu pada mulanya rasa sedih atas kematian orang tuanya, kemudian ada anggota keluarganya yang merasa dirinya “waris” dari orang yang meninggal dunia. Dengan demikian mereka akan membicarakan tentang pewarisan pada harta yang ditinggalkan oleh pewaris dan juga membicarakan tentang bagaimana cara menyelesaikan hubungan-hubungan hukum yang ada antara orang yang meninggal dunia (di dalam hal ini disebut pewaris), dan keluarga yang ditinggalkan (ahli waris). Pada hakekatnya hubungan-hubungan hukum yang diselesaikan itu berupa hak dan kewajiban baik yang dapat dinilai dengan uang maupun yang tidak dapat dinilai dengan uang (non materil).

Sebagaimana yang dikemukakan A Pitlo, 1984 bahwa hukum waris adalah : "Kumpulan peraturan yang mengatur mengenai kekayaan yang ditinggalkan oleh si mati dan akibat hukum dari perpindahan tersebut bagi yang memperolehnya, baik dalam hubungan antara mereka dengan mereka, maupun dalam hubungan antara mereka dengan pihak ketiga”.

Pada asasnya hak-hak dan kewajiban-kewajiban hukum dalam lapangan hukum kekayaan atau harta benda saja yang dapat diwariskan, sebagaimana yang dijelaskan Efendi Perangin, 2003 yaitu : “Ada beberapa kekecualian, misalnya hak seorang bapak untuk menyangkal sah anaknya untuk menuntut supaya ia dinyatakan anak yang sah dari bapak atau ibunya (kedua hak itu adalah dalam lapangan hukum kekeluargaan), dinyatakan dalam undang-undang diwarisi oleh ahli warisnya”. Namun di dalam hukum Indonesia, pewarisan dengan menganut 
sistem individual, dimana harta warisan tersebut harus segera dibagikan dan setiap ahli waris mendapatkan pembagian warisan untuk dapat menguasai atau memiliki harta warisan menurut bagiannya masing-masing. Seperti yang dijelaskan oleh Hilman Hadikusuma, 2003 yaitu : “Adapun harta warisan ini kemudian diadakan yang berakibat para waris dapat menguasai dan memiliki bagian untuk dapat dinikmati, diusahakan ataupun, dialihkan kepada anggota kerabat, ataupun orang lain”.

Sehubungan dengan itulah di dalam pengaturan penyelesaian masalah hak-hak yang berhubungan terhadap warisan ini semestinya diatur dengan suatu ketentuan hukum yang selaras dengan kayakinan masyarakat itu sendiri. Dengan Demikian latar belakang masalah dan pemikiran tersebut di atas itulah sebabnya pemerintah Indonesia memberlakukan suatu Undang-undang tentang Peradilan Agama yaitu Undang-undang Nomor 50 Tahun 2009 yang isinya mengatur tentang penyelesaian masalah-masalah hukum yang berkaitan dengan hakhak orang yang beragama Islam seperti masalah warisan.

Berdasarkan tersebut di atas ditegaskan bahwa peradilan Agama berdasarkan Undang-undang Nomor 50 Tahun 2009 merupakan salah satu pelaksanaan kekuasaan kehakiman bagi rakyat pencari keadilan yang beragama Islam mengenai perkara perdata yang artinya setiap persoalan hukum yang menyangkut hukum Islam seperti masalah pembagian harta warisan harus diselesaikan dengan melalui proses peradilan agama. Akan tetapi dalam kenyataan yang berkembang dalam masyarakat sampai dengan sekarang masih banyak mengajukan persoalan-persoalan hukum Islam seperti pembagian warisan ini dengan melalui jalur Pengadilan Negeri dan pada kenyataannya pula aparat Pengadilan Negeri sendiripun masih menerima hal ini sebagai suatu kewenangannya. Sehubungan dengan itulah jelas apa yang telah diatur dalam Undang-undang Nomor 50 Tahun 2009 tersebut tidak sesuai dengan apa yang berkembang dalam praktek sehingga dengan keadaan yang demikian penulis tertarik mengangkat masalah ini sebagai topik dalam penelitian skripsi dengan mengangkat judul sebagai berikut : “Eksepsi Terhadap Kewenangan Pengadilan Negeri Padangsidimpuan Dalam Mengadili Pembagian Harta Warisan”

\section{METODE PENELITIAN}


Berdasarkan penjelasan penulis tersebut di atas maka lokasi penelitian adalah pada Pengadilan Negeri Padangsidimpuan sebab lokasi tersebut ada hubungannya dengan penulisan penelitian ini serta bila dikaitkan dengan rumusan permasalahan dalam penelitian akan terjawab nantinya. Selanjutnya sebelum penulis menguraikan metode apa yang akan penulis buat dalam penelitian ini terlebih dahulu akan dijelaskan pengertian dari pada penelitian seperti yang dikemukakan oleh J. Suprapto, 2007 yaitu : "Suatu penyelidikan dari suatu bidang ilmu pengetahuan yang dijalankan untuk memperoleh fakta-fakta atau prinsipprinsip dengan sabar, hati-hati serta sitematis”. Sesuai dengan pengertian penelitian yang dijelaskan tersebut di atas maka penulis akan merumuskan metode penelitian yang akan digunakan dalam penelitian ini yaitu :

1. Penelitian Kepustakaan (Library Researchi) yaitu dengan metode penelitian yang mempelajari luiteratur yang ada hubungannya dengan masalah yang telah dirumuskan dalam penelitian ini

2. Penelitian Lapangan (Field Research) yaitu dengan metode penelitian melakukan wawancara kelapangan untuk menemui para responden yang ditentukan sebelumnya seperti Pengadilan Negeri Padangsidimpuan

\section{Jenis Penelitian Yang Digunakan}

Sesuai dengan tentang pengertian penelitian tersebut di atas selanjutnya penulis akan mengemukakan jenis penelitian yang digunakan yaitu dengan penelitian normatif suatu penelitian yang didasarkan kepada peraturan perundang-undanagan serta putusan dari pengadilan seperti putusan Nomor : 32/PDT.G/2013/PN.PSP yang ada kaitannya dengan masalah yang dihadapi dalam penelitian ini.

\section{Populasi Dan Sampel}

\section{Populasi}

Sesuai dengan lokasi penelitian yang penulis sebutkan di atas selanjutnya akan dirumuskan populasi dalam penelitian ini akan tetapi sebelum penulis mengemukakan populasinya terlebih dahulu dikemukakan pengertian populasi menurut H. Hadari Nawawi, 1990 yaitu : "Keseluruhan obyek penelitian yang dapat terdiri dari manusia, benda-benda, hewan, tumbuh-tumbuhan, gejala-gejala nilai test, peristiwa-peristiwa sebagai sumber daya dimiliki karakteristik tertentu di dalam suatu penelitian”. Selanjutnya sesuai dengan penjelasan tersebut di atas maka populasi yang diambil dalam penulisan penelitian ini adalah Hakim 
yang berada di Pengadilan Negeri Padangsidimpuan dan berupa putusan yang telah berkekuatan hukum tetap

\section{Sampel}

Selanjutnya penulis akan mengambil sampel terhadap penelitian ini, akan tetapi terlebih dahulu dikemukakan pengertian sampel seperti yang dijelaskan oleh Sudjana yaitu : "Bagian dari populasi yang dipergunakan sebagai sumber data yang sesungguhnya dalam penelitian” (Sudjana, 2008). Sesuai dengan kutipan tersebut di atas maka penulis akan mengambil sampel sebagai berikut yaitu : seorang Hakim yang berada di Pengadilan Negeri Padangsidimpuan dan putusan yang berkekuatan hukum tetap

\section{Sumber Data}

Setelah diuraikan tentang sampel dan populasi, maka penulis akan menjelaskan tentang pengambilan sumber data yaitu :

1. Data Primer adalah suatu data yang diambil dari hasil wawancara penulis dengan para responden

2. Data Skunder adalah suatu data yang diambil dari buku-buku yang ada di perpustakaan dan Putusan Pengadilan sesuai dengan penelitian ini

\section{Teknik Pengumpulan Data}

Sedangkan teknik atau alat yang penulis gunakan dalam mengumpulkan data baik dilapangan maupun dalam melakukan wawancara dengan responden serta dengan mempelajari dokumen yang ada hubungan dengan permasalahan penelitian ini adalah dengan sebagai berikut :

1. Interview (Wawancara) yaaitu dengan mengajukan pertanyaan-pertanyaan secara langsung kepada responden yang sebelumnya telah ditentukan terlebih dahulu

2. Studi Dokumentasi yaitu dengan mempelajari berkas-berkas yang telah diarsipkan di Pengadilan Negeri Padangsidimpuan

\section{Analisa Data}

Selanjutnya penulis akan menganalisa data-data yang ada dalam penelitian ini sebelumnya akan diuraikan tentang pengertian analisa data menurut pendapat Analisi Data adalah : "Mengolah data dengan menggunakan metode analisis yang dimaksudkan untuk mendapatkan pengetahuan ilmiah dengan mengadakan pemerincian terhadap objek yang 
diteliti dan menggabungkan beberapa pengertian diharapkan akan di dapatkan pengetahuan baru untuk pemahaman dan kejelasan arti yang dipahami” (Sudarto, 1997).

Sesuai dengan hasil kutipan tersebut di atas, maka untuk melakukan penganlisaan terhadap penelitian ini adalah dengan mengolaha data-data yang telah diuraikan di dalam penelitian sesuai dengan objek penelitian dengan penggabungkan beberapa pengertian serta dengan melakukan pemahaman terhadap hasil penelitian dengan memakai :

1. Induksi yaitu dengan mengolah data penelitian dari hal-hal yang brsifat khusus untuk mengambil suatu kesimpulan pada hal-hal yang bersifat umum

2. Deduksi yaitu dengan mengolah data penelitian dari hal-hal yang bersifat umum untuk mengambil suatu kesimpulan pada hal-hal yang bersifat khusus

\section{PEMBAHASAN}

\section{Kewenangan Pengadilan Negeri Dalam Memeriksa Dan Mengadili Perkara Harta Warisan}

Berlakunya Undang-undang Nomor 50 tahun 2009 perubahan atas Undang-undang 3 Tahun 2006 dan perubahan Undang-undang Nomor 7 Tahun 1989 untuk mengatur status dan kewenangan Pengadilan Agama sebagai Pengadilan bagi orang-orang yang beragama Islam kiranya telah menempatkan keberadaan Pengadilan pada Proforsi yang sebagaimana ditentukan pada Pasal 1 ayat (5) Undang-undang Nomor 48 Tahun 2009 secara tegas diatur bahwa selalu empat badan peradilan yang terdapat di Indonesia ini juga dimana peradilan Agama telah dinyatakan sebagai suatu badan hukum yang berdiri sendiri sejajar dengan dengan badan peradilan lainnya seperti peradilan umum, peradilan militer, peradilan tata usaha negara dan oleh sebuah Mahkamah Konstitusi.

Sehubungan dengan itulah seperti yang ditegaskan oleh Hakim Pengadilan Negeri Padangsidimpuan bahwa khusus masalah warisan yang berhubungan dengan orang-orang yang menganut agama Islam adalah kewenangan dari Peradilan Agama yang mana hal ini secara tegas diatur dalam ketentuan Pasal 49 Undang-undang Nomor 50 Tahun 2009 tentang Peradilan Agama. Namun demikian penegasan tersebut di atas selanjutnya dijelaskan oleh Hakim Pengadilan Negeri Padangsidimpuan mengatakan bahwa kewenangan yang dimaksudkan dalam ketentuan Pasal 49 Undang-undang Nomor 50 tahun 2009 sebagaimana pengganti dari Undang-undang Nomor 7 Tahun 1989 serta Undang-undang Nomor 3 Tahun 2006 tersebut tidaklah bersifat mutlak setiap sengketa masalah warisan orang-orang 
beragama Islam harus melalui Pengadilan Agama melainkan Pengadilan Negeri dengan kewenangan yang ada padanya cukup berwenang dan mempunyai dasar hukum di dalam Undang-undang Nomor 48 Tahun 2009 yang menetapkan bahwa Pengadilan Negeri sebagai Pengadilan tingkat pertama berwenang mengadili semua perkara baik perdata maupun pidana. Sehubungan dengan ketentuan tersebut dengan adanya istilah semua pada rumusan itu jelas memberikan kewenangan bagi Pengadilan Negeri untuk mengadili atau menyidangkan semua bentuk perkara atau dengan kata lain tidak ada alasan untuk tidak memeriksa di hadapan sidang Pengadilan.

Kemudian lebih lanjut Hakim Pengadilan Negeri Padangsidimpuan menegaskan bahwa juga dasar kewenangan tersebut ditentukan dalam Pasal 10 ayat (1) Undang-undang Nomor 48 Tahun 2009 yang mengatakan bahwa pengadilan tidak boleh menolak untuk memeriksa, mengadili dan memutus suatu perkara yang diajukan dengan dalih bahwa hukum tidak ada atau kurang jelas melainkan wajib untuk memriksa dan mengadilinya. Dengan dasar pemikiran seperti dijelaskan tersebut di atas menurut Hakim Pengadilan Negeri Padangsidimpuan yang penulis sebutkan namanya di atas mengatakan Hakim dilarang untuk menyatakan bahwa sekalipun masalah warisan Islam harus tetap diperiksa dan diadili karena jika seandainya Pengadilan Negeri menolak dengan alasan tidak berwenang jelas akan bertentangan dengan ketentuan Pasal 10 Undang-undang Nomor 48 Tahun 2009 tersebut.

Berdasarkan uraian tersebut di atas jelas dihubungkan dengan data yang terdapat dalam putusan Pengadilan Negeri Padangsidimpuan Nomor 32/PDT.G/2013/PN.PSP dimana tergugat tidak ada mengajukan keberatan tentang masalah kewenangan Hakim Pengadilan Negeri Padangsidimpuan untuk memeriksa perkara tersebut, sehingga keadaan yang seperti inipun Hakim Pengadilan Negeri Padangsidimpuan semakin menguatkan kewenangan Pengadilan Negeri untuk memeriksa perkara tersebut sekalipun itu sengketa harta warisan. Dengan kata lain selanjutnya menurut Hakim Pengadilan Negeri Padangsidimpuan jika seandainya para pihak berperkara baik penggugat maupun tergugat keberatan disidangkan di Pengadilan Negeri akan mengajukan eksepsi tentang hal ini, sedangkan eksepsi yang diajukan oleh tergugat telah ditolak oleh Hakim Pengadilan Negeri, sesuai dengan ketentuan Pasal 10 ayat (2) yang menerangkan bahwa tidak menutup usaha untuk penyelesaian perkara perdata secara damai atau dengan kata lain memerintahkan kepada para pihak yang berperkara untuk melanjutkan pemeriksaan perkara ini sebagaimana yang terdapat dalam putusan Pengadilan Negeri Padangsidimpuan Nomor 32/PDT.G/2013/PN.PSP tersebut. 
Namun demikian menurut Hakim Pengadilan Negeri Padangsidimpuan selain ketentuan Pasal 49 Undang-undang Nomor 50 tahun 2009 sebagaimana pengganti dari Undang-undang Nomor 3 Tahun 2006 serta Undang-undang Nomor 7 tahun 1989 masalah kewenangan mengadili khususnya tentang sengketa yang menyangkut orang yang beragama Islam harus di dasarkan juga pada ketentuan Pasal 50 Undang-undang Nomor 50 tahun 2009 yang juga mengatur masalah kewenangan mengadili. Dimana dalam ketentuan Pasal 10 tersebut di atas selanjutnya menurut Hakim Pengadilan Negeri Padangsidimpuan telah dibatasi kewenangan Pengadilan Negeri untuk mengadili masalah-masalah warisan Islam yaitu apabila di dalam sengekata tersebut terdapat sengketa hak milik atas obyek yang disengketakan barulah Pengadilan Negeri berwenang, sedangkan jika sengketa ini khususnya persoalan pembagian diantara para ahli waris hal itu mutlak wewenang Pengadilan Agama. Lebih lanjut di tegaskan oleh Hakim Pengadilan Negeri Padangsidimpuan bahwa untuk memperkuat penjelasan di atas dapat dibandingkan dengan salah satu Yurisprudensi Mahkamah Agung RI, Nomor 11.K/AG/1979 menegaskan bahwa apabila dalam suatu gugatan yang menyangkut pembagian harta warisan masih terkandung sengketa hak milik maka perkara yang bersangkutan tidak termasuk kewenangan Pengadilan Agama untuk memeriksanya tetapi termasuk kewenangan Pengadilan Umum (Negeri).

Dengan demikian dalam hubungan dengan perkara dalam putusan Pengadilan Negeri Padangsidimpuan Nomor, 32/PDT.G/2013/PN.PSP adalah masalah sengketa kepemilikan harta warisan yang dikuasai oleh tergugat yang diajukan oleh Penggugat ke sidang pengadilan. Berdasarkan uraian tersebut di atas, maka dengan demikian apa yang ditetapkan Hakim Pengadilan Negeri Padangsidimpuan dalam amar putusannya yang menyatakan bahwa tentang eksepsi kewenangan mengadili (Eksepsi Abosolut) yang diajukan oleh tergugat dapat dikabulkan oleh Hakim karena di dalam isi eksepsi tergugat menyatakan bahwa gugatan Para Penggugat merupakan gugatan kurang pihak atau dapat dikatakan gugatan penggugat kabur dan tidak jelas.

\section{Faktor Penolakan Eksepsi Terhadap Surat Gugatan Perkara Perdata}

Berdasarkan kepada data pada penjelasan di atas sebagaimana yang diuraikan pada ulasan terdahulu dimana keberadaan eksepsi sebagai upaya atau perlawanan pihak tergugat terhadap gugatan yang sedang dihadapinya masih menunjukkan perkembangan yang kurang menggembirakan jika dilihat dari persentase perkara perdata yang masuk. Sehubungan dengan itulah untuk mengetahui sebab-sebab keberadaan eksepsi masih ditolak oleh Hakim 
pada Pengadilan Negeri Padangsidimpuan berikut ini akan diuraikan secara rinci sesuai dengan kenyataan yang terjadi dalam praktek.

Faktor Materi Eksepsi.

Sebagai faktor pertama yang menyebabkan eksepsi yang diajukan tergugat untuk penolakan surat gugatan yang diajukan penggugat dalam persidangan adalah menyangkut materi yang dirumuskan dalam eksepsi tersebut yang mana seperti dijelaskan menurut Hakim Pengadilan Negeri Padangsidimpuan hukumnya masih mengajukan materi eksepsi yang menyangkut kepada pokok perkara sehingga kalau pokok perkaranya yang dipermasalahkan dalam eksepsi jelas tidak dapat diterima karena sebagaimana diketahui bahwa mempermasalahkan pokok perkara itu memerlukan pembuktian. Sehubungan dengan itulah semestinya materi yang dimasukkan sebagai dasar pengajuan eksepsi hanya persoalan-persoalan yang menyangkut hukum acara saja apakah sesuai dengan atau tidak dengan ketentuan hukum acara maupun apakah telah sesuai dengan persoalan-persoalan prosedur pengajuan suatu gugatan. Bilamana penjelasan Hakim tersebut di atas jika dikaitkan dengan perkara perdata dalam putusan Nomor 32/PDT.G/2013/PN.PSP yang diangkat sebagai data kasus pada penelitian ini kiranya jelas terbukti bahwa eksepsi ini masih mempersoalkan materi yang berkaitan dengan pokok perkara yang mana hal ini sebagaimana terlihat dalam pertimbangan Hakim dalam putusan tersebut yang berbunyi bahwa dalam hal lamanya penguasaan suatu obyek perkara oleh pihak baru muncul gugatan dari pihak lain adalah menyangkut pokok perkara maka hak tersebut akan dipertimbangkan dalam pokok perkara.

Faktor Penguasaan Hukum.

Sebagai faktor kedua sebagai alasan ditolaknya eksepsi adalah menyangkut penguasaan hukum yang berhubungan dengan hukum-hukum acara baik yang diatur dalam peraturan Perundang-undangan maupun yang diatur melalui Yurisprudensi Mahkamah Agung RI. Dikatakan demikian karena oleh hukum acara perdata ini masih banyak berpedoman kepada perkembangan dilapangan menyebabkan apa yang tidak diperbolehkan pada masa acara sidang selama ini akan tetapi dengan perkembangan Yurisprudensi dapat dilakukan bilamana sesuai dengan kenyataan yang dihadapi secara kasus perkasus. Berdasarkan penjelasan tersebut di atas sebagaimana dinyatakan oleh Hakim Pengadilan Negeri Padangsidimpuan misalnya seorang tergugat atau melalui kuasanya mengetahui bahwa bagi seseorang yang mau mengajukan gugatan warisan harus diikut sertakan semua ahli waris demikian juga dari sudut tergugat dahulu harus semuanya diikut sertakan dalam surat gugatan akan tetapi dengan perkembangan hukum sebagaimana dituangkan dalam Yurisprudensi hal seperti itu tidak perlu dilakukan tetapi cukup dari beberapa orang saja. 
Demikian juga dalam hal ini sebagaimana dijelaskan dalam pertimbangan putusan perkara perdata Nomor 32/PDT.G/2013/PN.PSP tersebut dimana tergugat atau melalui kuasa hukumnya mempersoalkan masalah seperti tersebut di atas dalam eksepsinya akan tetapi oleh Hakim menolak alasan demikian dengan dasar pertimbangan Hakim adalah masalah tentang masih kurangnya para pihak yang ikut dalam gugatan yang diajukan oleh pengggat. Bahwa tidak semua ahli waris mengajukan gugatan tidaklah hal tersebut merugikan tergugat-tergugat karena sebagaimana ditegaskan dalam Yurisprudensi Mahkamah Agung RI No. 224.K/Sip/1959 tanggal 5 Januari Yo Nomor 516.K/Sip/1973 tanggal 25 Nopember 1975 cukup siapa-siapa yang langsung menguasai obyek perkara yang digugat tersebut. Demikian juga dalam Yurisprudensi lain yaitu Nomor 305.K/Sip/1971 tanggal 16 Juni 1973 diberikan wewenang kepada penggugat untuk menentukannya siapa-siapa yang mau digugatnya maka dengan kedua alasan tersebut eksepsi dari tergugat-tergugat ini haruslah ditolak semuanya.

Faktor Pemahaman Gugatan.

Selain faktor tersebut di atas juga alasan ditolaknya eksepsi yang diajukan tergugat untuk melawan surat gugatan bisa pula dilihat dari kurangnya pemahaman terhadap apa yang menjadi isi gugatan penggugat sehingga menurut Hakim Pengadilan Negeri Padangsidimpuan tidak jarang para pihak tergugat atau melalui kuasanya mengajukan eksepsi tanpa ada hubungannya dengan hal ada dalam surat gugatan, dengan kata lain bisa pula pihak tergugat-tergugat maupun melalui kuasanya menyebutkan suatu surat gugatan itu kabur dan tidak jelas apa obyek perkaranya akan tetapi tidak diterangkan lebih lanjut obyek apa dan bagaimana yang dimaksudkan tersebut. Berdasarkan seluruh uraian tersebut di atas kiranya jelaslah bahwa faktor ditolaknya seksepsi yang diajukan tergugat untuk terhadap surat gugatan dari penggugat di sidang Pengadilan yang penting diantaranya adalah tentang materinya, dimana menurut Hakim Pengadilan Negeri Padangsidimpuan Andy William Permata, SH masalah ini harus benar-benar diperhatikan dengan secara seksama karena materi eksepsi tidak sama dengan materi pada replik atau duplik yang sudah mengarahkan persoalan pada pokok perkara.

\section{Pertimbangan Hakim Pengadilan Negeri Dalam Kewenangan Mengadili Dan Memeriksa Harta Warisan}

Dengan memperhatikan seluruh data-data tentang masalah kewenangan untuk mengadili perkara-perkara warisan Islam jelas dengan berlakunya Undang-undang Nomor 50 tahun 2009 atas perubahan Undang-undang Nomor 3 tahun 2006 dan juga perubahan Undangundang Nomor 7 Tahun 1989 dimana dikatakan bahwa kewenangan Pengadilan sejauh hal itu 
menyangkut pembagian harta warisan untuk masing-masing ahli waris, dengan kata lain sebaliknya jika dalam masalah harta warisan tersebut ada yang terselip sengketa hak milik barulah menjadi wewenang Pengadilan Negeri. Akan tetapi dengan melihat sengketa yang terdapat pada Putusan Pengadilan Negeri Padangsidimpuan Nomor. 32/PDT.G/2013/PN.PSP jelas yang menjadi pokok sengketa diantara para ahli waris adalah untuk kepentingan hak mengenai kepemilikan harta warisan yang ditinggalkan oleh orang tua mereka hal ini seharusnya dapat disidangkan dengan melalui Pengadilan Negeri.

Selanjutnya menurut pendapat Hakim Pengadilan Negeri Padangsidimpuan bahwa alasan pertimbangan untuk memeriksa sengketa masalah warisan di Pengadilan Negeri karena selain perkara tersebut telah masuk kewenangan Pengadilan Negeri dengan terbuktinya dari Nomor Register perkara Nomor 32/PDT.G/2013/PN.PSP menyebabkan Hakim yang ditunjuk dengan dasar Undang-undang Nomor 48 Tahun 2009 wajib untuk memeriksanya sebatas wewenang yang ada pada Hakim. Kemudian keharusan tersebut juga diperkuat dengan adanya permohonan pihak penggugat kepada Mejalis di dalam gugatannya agar diperiksa sesuai dengan aturan hukum yang berlaku, yang mana hal ini terbukti dari pernyataan penggugat dalam Putusan Nomor. 32/PDT.G/2013/PN.PSP yang menyatakan bahwa penggugat agar kiranya suatu hari menentukan persidangan dalam perkara dan menyuruh pemanggilan pihak berperkara untuk menghadap dipersidangan guna untuk memeriksa dan mengadilinya. Berdasarkan permohonan dari penggugat sebagaimana dijelaskan di atas menurut Hakim Pengadilan Negeri Padangsidimpuan merupakan suatu bukti bahwasanya perkara tersebut harus disidangkan di Pengadilan Negeri, yang mana hal ini di dasarkan kepada azas bahwa setiap orang dapat menentukan dan memilih melalui Pengadilan Agama atau Pengadilan Negeri ia akan menuntut haknya. Akan tetapi selanjutnya menurut salah seorang Hakim Pengadilan Negeri Padangsidimpuan tersebut di atas menjelaskan bahwa keberadaan azas untuk menuntut hak tersebut memang diakui keberadaannya dalam hukum dan sepenuhnya diberikan kebebasan bagi setiap pencari keadilan untuk menentukannya, namun dengan adanya Undang-undang yang telah mengatur acara bagi masyarakat menuntut haknya jelas azas tersebut harus dikesampingkan yang artinya penyelesaian sengketa tersebut harus dikembalikan kejalur peraturan yang sudah secara positif dinyatakan berlaku. Berdasarkan alasan itu untuk membuktikan bahwa Hakim pada Pengadilan Negeri tidak berwenang untuk memeriksanya dan mengadilinya, apalagi alasan ini dihubungkan dengan keterangan penggugat yang dijadikan Hakim sebagai suatu pertimbangan yang berbunyi bahwa harta milik penggugat adalah harta warisan dari orang tua penggugat Alm. H. Abdul Manap 
Nasution. Karena menurut Hakim Pengadilan Negeri Padangsidimpuan bahwasanya keterangan penggugat dalam pertimbangan tersebut di atas menunjukkan kejelasan masalah yang menjadi sengketa adalah persoalan pemilikan dan pembagian harta warisan yang diperolehnya dari orang tua penggugat Alm H. Abdul Manap Nasution, akan tetapi kenyataanya sebagaimana dijelaskan tersebut di atas menurut Hakim Pengadilan Negeri Padangsidimpuan telah dijadikan dasar pertimbangan pada putusan Nomor. 32/PDT.G/2013/PN.PSP yang berbunyi menolak eksepsi tentang kewenangan mengadili (Eksepsi Absolut) dari tergugat, menyatakan Pengadilan Negeri Padangsidimpuan tidak berwenang memeriksa dan mengadili perkara ini, memerintahkan kepada para pihak yang berperkara untuk melanjutkan pemeriksaan perkara ini dan menangguhkan tentang penentuan besarnya biaya perkara sampai pada putusan akhir, maka dapat disimpulkan bahwa pada putusan tersebut di atas sudah terjadi putusan yang dinamakan dengan putusan dimana para pihak yang berperkara untuk melanjutkan pemeriksaannya kembali.

Lebih lanjut dasar pertimbangan tersebut dilakukan Hakim pada putusannya juga didasarkan kepada pertimbangan lainnya dimana penggugat maupun tergugat telah memberikan jawaban dalam persidangan bahwa pada pokonya membenarkan silsilah keturunan dan harta-harta warisan sehingga membuktikan bahwa benar harta terperkara sebagai harta peninggalan

\section{KESIMPULAN DAN SARAN}

\section{Kesimpulan}

a. Bahwa kewenangan Hakim Pengadilan Negeri dalam mengadili perkara pembagian harta warisan sudah berkekuatan hukum sekalipun sudah terbentuknya Undang-undang Nomor 50 tahun 2009 perubahan atas Undang-undang Nomor 3 Tahun 2006 dan juga perubahan Undang-undang Nomor 7 Tahun 1989 yang mengatur tentang kewenangan Pengadilan Agama karena tidak terlepas dari Undang-undang Nomor 48 Tahun 2009 tentang Pokok Kekuasaan Kehakiman yang menyatakan Pengadilan Negeri berhak mengadili dan memeriksa perkara harta warisan akan tetapi kita tidak boleh terlepas dengan adanya Undang-undang yang berhak mengadili dan memeriksa serta memutus perkara harta warisan yaitu Pengadilan Agama

b. Bahwa kekuatan kewenangan Pengadilan Negeri untuk menyidangkan sengketa warisan Islam khususnya tentang masalah yang berkaitan dengan sengketa kepemilikan harta warisan adalah bersifat mutlak akan tetapi pelaksanaan putusan yang dikeluarkan 
berdasarkan kewenangan Hakim Pengadilan Negeri yang sesuai dengan apa yang terdapat di dalam Undang-undang Nomor 48 Tahun 2009

\section{Saran}

a. Bahwa oleh karena pelaksanaan tugas suatu badan peradilan baik itu dalam Peradilan Agama maupun Peradilan Umum (Negeri) adalah merupakan dasar utama menentukan kewenangan untuk memeriksa dan mengadili sesuatu perkara harta warisan, dimana Pengadilan Agama memeriksa dan mengadili tentang pembagian harta warisan sedangkan Pengadilan Umum (Negeri) memeriksa dan mengadili tentang masalah hak kepemilikan harta warisan, maka atas kedua peradilan itu seharusnya berhak untuk mengadili pembagian harta warisan ataupun diadakannya suatu penyuluhan hokum terhadap masyarakat agar mereka mengetahui ke peradilan manakah mereka mengajukan gugatan tentang pemebagian harta warisan apabila terjadi perselisihan pembagian

b. Bahwa oleh karena antara Pasal 49 Undang-undang Nomor 50 Tahun 2009 telah diberlakukan sebagai dasar bagi Pengadilan Agama untuk menyidangkan pembagian harta warisan kiranya keberadaan Pasal 10 Undang-undang Nomor 48 Tahun 2009 yang melarang Pengadilan Negeri menolak setiap perkara yang masuk sudah jelas ditegaskan bahwa Hakim tidak bolah menolak memeriksa dan mengadili perkaraperkara dengan alasan tidak berwenang ataupun dengan alasan tidak jelas, karena apabila perkara tersebut mengenai masalah tentang hak kepemilikan terhadap harta warisan maka Pengadilan Negeri berhak mengadili dan memeriksanya.

\section{DAFTAR PUSTAKA}

A Pitlo, 1984, Hukum Waris, Pramadya Paramita, Jakarta

Efendi Perangin, 2003. Hukum Waris, Raja Grafindo Persada, Jakarta

Hilman Hadikusuma, 2003. Hukum Waris Adat. Citra Aditya Bakti, Bandung

Kurdianto, 1987, Sistem Pembuktian Hukum Acara Perdata Dalam Teori Dan Praktek, Usaha Nasional, Surabaya.

Elisa T. Sulistini dan Rudy T. Erwin, 1987, Petunjuk Praktis Menyelesaikan Perkara Perdata, Bina Aksara, Jakarta

Sudikno Mertokusumo, 1982, Pengantar Hukum Waris Islam, Sinar Grafika, Jakarta 
Ny. Retnowulan Sutantio, 1979, Hukum Acara Perdata Dalam Teori Dan Praktek, Alumni, Bandung

Muhammad Arief, 1986, Hukum Kewarisan Dalam Islam, Bina Timur, Surabaya

M. Ali Hasan, 1981, Hukum Warisan Dalam Islam, Bulan Bintang, Jakarta

Idris Djakfar. 1995, Kompilasi Hukum Kewarisan, Pustakan Jaya, Jakarta

Sudikon Mertokusumo, 1982, Hukum Acara Perdata Indonesia, Liberti , Yogyakarta

J. Suprapto, 2007, Mmetodologi Penelitian Hukum, Sinar Grafika, Jakarta

H. Hadari Nawawi, 1990, Metode Penelitian, Raja Grafindo, Jakarta

Sudjana, 2008, Metodologi Penelitian, Sinar Grafindo, Grafindo, Jakarta

Sudarto, 1997, Metodologi Filsafat, Raja Grafindo Persada

Departemen Kehakiman RI, 1986, Bahan Pokok Penyuluhan Tentang Undang - undang Dasar 1945, Jakarta

Departemen Kehakiman Republik Indonesia, 2004, Undang-undang Nomor 4 Tahun 2004 Tentang Pokok Kekuasaan Kehakiman, Jakarta

Mahkamah Agung RI, 1985, Undang-undang Nomor 14 Tahun 1985 Tentang Mahkamah Agung, Jakarta

Departemen Kehakiman Republik Indonesia, 2009, Undang-undang Nomor 48 Tahun 2009 Tentang Pekok Kekuasaan Kehakiman, Jakarta 